\title{
Tumor Necrosis Factor-alpha -308G/A Polymorphism Associated with Increased Risk for Pulmonary Tuberculosis in Medan City, Indonesia
}

\author{
Bintang Yinke Magdalena Sinaga*, Zainuddin Amir \\ Department of Pulmonology and Respiratory Medicine, Faculty of Medicine, Universitas Sumatera Utara, Medan, Indonesia
}

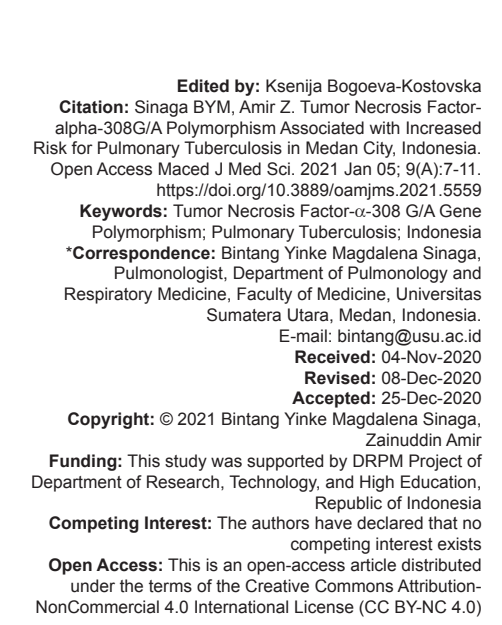

Introduction

Pulmonary tuberculosis (PTB) is a global public health problem, presenting a high incidence in Indonesia [1]. It is estimated that about one-third of the world's population is affected by this disease. However, only $5-10 \%$ of an infected person develops the disease [2]. Many factors influence the individual to develop this disease. Besides the environmental factors, host genetic factors play roles in susceptibility to tuberculosis (TB). Twin studies have shown that monozygotic twins have a higher concordance for TB compared with dizygotic twins or other siblings [3]. Some genes have been identified in TB susceptibility and one of these is tumor necrosis factor alpha (TNF- $\alpha$ ) gene [4], [5].

TNF- $\alpha$ is a pro-inflammatory cytokine that plays an important role in host defense to TB in humans. It was produced mainly by monocytes and macrophages and also by neutrophils, T cells, and natural killer cells [6]. TNF- $\alpha$ plays an essential role in forming granuloma formation by recruitment of immune cells to the site of infection, increasing the ability of macrophage for controlling the intracellular mycobacteria, stimulating the apoptosis of macrophage, and maintaining the granuloma formation [7], [8]. Some studies found that TNF- $\alpha$ blockage in patients treated with anti-TNF- $\alpha$ results in TB disseminated [9].

The TNF- $\alpha$ cytokines are encoded by TNF- $\alpha$ gene which is located within the major histocompatibility complex class III, a highly polymorphic region on chromosome $6 \mathrm{p} 21$. There are many single-nucleotide polymorphisms (SNPs) in the promotor of this region [10]. The SNPs were the most common genetic variation of TNF- $\alpha$ gene and were considered in influencing the transcription of TNF- $\alpha$ cytokine. Some SNPS of TNF- $\alpha$ gene have been identified at positions $-238,-308,-857$ and -863 . One of the most important polymorphisms is $-308 \mathrm{G} / \mathrm{A}$ polymorphism. Some studies found that $A$ allele has higher transcriptional activity compared to the G allele [11], [12], [13].

The study of this association is inconclusive because different results were found for the association of TNF- $\alpha$ gene -308 polymorphism and susceptibility to PTB in several ethnic groups and different populations. Some studies reported a significant association [14], [15], [16], but other studies were not significant [17], [18]. Therefore, 
further studies are needed to clarify these results. This study aims to investigate whether TNF $\alpha-308 \mathrm{G} / \mathrm{A}$ gene polymorphism is associated with susceptibility to PTB in Medan city, Indonesia.

\section{Methods}

\section{Research design}

This is a case-control study with 100 subjects for each group. Consecutive sampling was used to look for the case group included the TB case and healthy people as control group. This study has approved by the Ethics Committee of the Faculty of Medicine, Universitas Sumatera Utara, Medan, Indonesia.

\section{Population and samples}

Cases were 100 PTB patients from several TB facilities in Medan. For the case group, the inclusion criteria were new TB cases, age $\geq 18$ years old, have symptoms of PTB, positive sputum smear, and chest $X$-ray consistent with PTB. The exclusion criteria in the case group were human immunodeficiency virus (HIV) positive, have diabetes mellitus and other severe comorbid diseases, and consuming immunosuppressive drugs. Control group was 100 healthy subjects from the community with no signs and symptoms of TB, normal chest X-ray, and no history of TB before. All subjects were interviewed and informed consent was obtained.

\section{Genotyping}

Genotyping was done from DNA samples that have been stored in laboratorium using minus $70^{\circ} \mathrm{C}$ refrigerator with the same inclusion and exclusion criteria in this study. TNF- $\alpha$ polymorphism genotyping was performed by polymerase chain reaction fragment length polymorphism (PCR-RFLP) method.

The genomic region encompassing the $-308 \mathrm{G} / \mathrm{A}$ polymorphism was amplified using the following primers: Forward 5'-AGGCAATAGGTTTTGAGGGCCAT-3' and reverse 5'-TCCTCCCTGCTCCGATTCCG-3'. PCR products then were digested with $\mathrm{Ncol}$ restriction enzyme. PCR product of -308 G/A TNF- $\alpha$ gene polymorphism before digested was $107 \mathrm{bp}$. After digested with the Ncol restriction enzyme, the AA genotype had one band (107 bp), AG genotype had three bands (107, 87, and $20 \mathrm{bp}$ ), and GG genotype had two bands (87 and $20 \mathrm{bp}$ ).

\section{Data analysis}

Data were managed and analyzed using IBM statistics ver. 24.0. The genotype frequencies of each SNP were compared by Chi-square test. The strength of the association was evaluated by calculating the odds ratio (OR) and 95\% confidence interval $(\mathrm{CI})$.

\section{Results}

Based on sex and age demographic characteristics, the number of male subjects was more than female subject and most of the subjects were in productive age in both groups, mainly in 20-39 years old followed by $40-59$ years old (Table 1 ).

Table 1: Demographic characteristics

\begin{tabular}{|c|c|c|c|c|}
\hline \multirow[t]{2}{*}{ Characteristics } & \multicolumn{2}{|c|}{ Case } & \multicolumn{2}{|c|}{ Control } \\
\hline & $n$ & $\%$ & $n$ & $\%$ \\
\hline \multicolumn{5}{|l|}{ Sex } \\
\hline Male & 68 & 68.0 & 73 & 73.0 \\
\hline Female & 32 & 32.0 & 27 & 27.0 \\
\hline \multicolumn{5}{|l|}{ Age (years) } \\
\hline$<20$ & 12 & 12.0 & 2 & 2.0 \\
\hline $20-39$ & 60 & 60.0 & 71 & 71.0 \\
\hline $40-59$ & 26 & 26.0 & 26 & 26.0 \\
\hline$\geq 60$ & 2 & 2.0 & 1 & 1.0 \\
\hline Total & 100 & 100 & 100 & 100 \\
\hline
\end{tabular}

Table 2 enlists the allele and the genotype frequencies for TNF- $\alpha-308 \mathrm{G} / \mathrm{A}$ polymorphism. In the case group, the AA genotype was not found and the AG genotype was more than the GG genotype. The comparison of the allele and genotype frequencies showed a significant difference between TB patients and controls with $p=0.002$ and $<0.001$, respectively.

Table 2: Distribution of -308 polymorphism genotype in PTB case and control

\begin{tabular}{llll}
\hline Polymorphism & Case $\mathrm{n}(\%)$ & Control $\mathrm{n}(\%)$ & p-value \\
\hline Genotype & & & \\
AA & 0 & 2 & $<0.001$ \\
AG & 80 & 47 & \\
GG & 20 & 51 & \\
Total & 100 & 100 & \\
Allele & & & 0.002 \\
A & 80 & 51 & \\
G & 120 & 149 & \\
Total & 200 & 200 & \\
\hline PTB: Pulmonary tuberculosis, Chi-square test. & &
\end{tabular}

Two comparative analyses were done to find the OR value for association of $-308 \mathrm{G} / \mathrm{A}$ polymorphism and susceptibility to PTB (Table 3 ). The first analysis is a recessive model ( $A A+A G$ genotype vs. $G G$ ) with OR 4.16; Cl 2.22 0-7.79; $p<0.001$, means $A A+A G$ genotypes individuals were 4.16 times more likely to suffer PTB compared to GG genotype. A secondary analysis was the homozygote model (AG vs. GG) with OR 4.3; Cl 2.31-8.15; $p<0.001$, means individuals with

Table 3: Association between -308 G/A TNF- $\alpha$ gene polymorphism and PTB

\begin{tabular}{|c|c|c|c|c|c|c|c|}
\hline \multirow[t]{2}{*}{ Polymorphism } & \multicolumn{2}{|c|}{ Case } & \multicolumn{2}{|c|}{ Control } & \multirow[t]{2}{*}{$p$-value } & \multirow[t]{2}{*}{$\overline{O R}$} & \multirow[t]{2}{*}{$95 \% \mathrm{Cl}$} \\
\hline & $n$ & $\%$ & $\mathrm{n}$ & $\%$ & & & \\
\hline$\overline{A A}$ and $\mathrm{AG}$ & 80 & 80.0 & 49 & 49.0 & $<0.001$ & 4.16 & $2.22-7.79$ \\
\hline GG & 20 & 20.0 & 51 & 51.0 & & & \\
\hline Total & 100 & 100 & 100 & 100 & & & \\
\hline AG & 80 & 80.0 & 47 & 47.9 & $<0.001$ & 4.3 & $2.31-8.15$ \\
\hline GG & 20 & 20.0 & 51 & 52.1 & & & \\
\hline Total & 100 & 100 & 98 & 100 & & & \\
\hline
\end{tabular}


AG genotype were 4.3 times more likely to suffer PTB compared to GG genotype.

There is also a significant association between an allele and PTB (Table 4). The A allele increased the risk of TB incidence compared to the $\mathrm{G}$ allele (OR 1.94; 95\% Cl 1.27-2.98, $p=0.002)$.

Table 4: Association between -308 G/A TNF- $\alpha$ gene polymorphism allele and PTB

\begin{tabular}{|c|c|c|c|c|c|c|c|}
\hline \multirow[t]{2}{*}{$\overline{\text { Allele }}$} & \multicolumn{2}{|c|}{ Case } & \multicolumn{2}{|c|}{ Control } & \multirow[t]{2}{*}{$p$-value } & \multirow[t]{2}{*}{ OR } & \multirow[t]{2}{*}{$95 \% \mathrm{Cl}$} \\
\hline & $\mathrm{n}$ & $\%$ & $\mathrm{n}$ & $\%$ & & & \\
\hline $\bar{A}$ & 80 & 40.0 & 51 & 25.5 & 0.002 & 1.94 & $1.27-2.98$ \\
\hline $\mathrm{G}$ & 120 & 60.0 & 149 & 74.5 & & & \\
\hline
\end{tabular}

The comparison of the association of $-308 \mathrm{G} / \mathrm{A}$ polymorphism TNF- $\alpha$ gene and TB in different population in the world is listed in Table 5. This study found that there is an association between -308 G/A polymorphism TNF- $\alpha$ gene and TB, same as several studies, but in other populations, there is no association between -308 G/A polymorphism TNF- $\alpha$ gene and TB.

\section{Discussion}

Single nucleotide of cytokine genes may influence the immune response by altering the level and function of secreted cytokine. Banerjee et al. indicated that high-level TNF- $\alpha$ serum was associated with the presence of -308 A allele and GA/AA genotype [26], and high-level production of TNF- $\alpha$ is considered as a risk factor for active pulmonary progression [27]. On the other hand, Cui et al. found that GA and AA genotype was associated with decreased serum TNF- $\alpha$ levels [28].

In this study, there was a significant association between the $-308 \mathrm{G} / \mathrm{A}$ polymorphism and susceptibility to PTB. This study was consistent with some studies but in contrast with several other studies that have shown no significant association between this polymorphism and TB. Table 5 shows the results of the association in different populations and ethnic in the world. Meta-analysis study from a diverse world population found that $-308 \mathrm{G} / \mathrm{A}$ polymorphism was associated with PTB in Africa, but not in Asian and Caucasian [29].

This discrepancy results may be due to ethnic-specific variation, a different definition of cases and control, and interaction between gene host, agent, and environment. Ethnic-specific genetic variation can influence the immune responses to microbial pathogens. Linkage disequilibrium in specific ethnic population can also affect the association studies [21]. Lifestyle factors such as smoking and alcohol consumption habits and food or diet type also influence the susceptibility to TB. Sinaga et al. found that smoking and alcohol consumption habits in one specific ethnic were the risk factor for PTB disease in Indonesia [30].

Gene interaction of the host, gene hostenvironment interaction, or gene host-agent interaction might influence the results. The opposing effect between the interaction of TNF- $\alpha$ gene and other genes should be accountable for the study. The balance between TNF- $\alpha$ and interleukin-10 was considered to be essential for controlling and dissemination of TB. Besides that, some studies found evidence of host genetics and Mycobacterium strain interaction for susceptibility to TB [31].

The difference in the cases defined also might be the cause of the different results. In some studies, cases were identified by smear positive and radiology while other studies used culture confirmed of TB cases. Some studies defined extra PTB as a case group. Coinfection such as HIV may influence the genetic susceptibility to TB. Some studies exclude HIV subjects while other studies included it. It is also important to note that different sources of control may influence the study results such as a history of TB exposure of the subjects.

In this study, the diagnosis was confirmed by microscopic and radiology, HIV status was done in the case group but not in the control group and the exposure history to TB cases in both groups was not defined. The interaction between host gene-gene, host agent, and the effect of lifestyle on our association results is also unknown.

Table 5: Association of -308 G/A polymorphism TNF- $\alpha$ gene and TB in different population

\begin{tabular}{|c|c|c|c|c|}
\hline Cases & Controls & Population & Reference & Results \\
\hline 100 PTB patients & $100 \mathrm{NC}$ & Indonesian & This study & Association with PTB \\
\hline 100 PTB patients & $100 \mathrm{NC}$ & Lur, Iranian & Shahsavar, et al. [14] & Association with PTB \\
\hline 138 TB patients & $419 \mathrm{NC}$ & Columbian & Correa, et al. [16] & Association with TB \\
\hline 636 TB patients & $608 \mathrm{NC}$ & Tibetan Chinese & Wu, et al. [15] & Association with TB \\
\hline 613 TB patients & $603 \mathrm{NC}$ & Han Chinese & Wu et al. [15] & No association with TB \\
\hline 140 PTB ( 30 with pleural TB and 20 with miliary TB) & 54 tuberculin negative, 81 tuberculin positive & Colombian & Henao et al. [17] & No association of TB \\
\hline 145 TB patients & $211 \mathrm{NC}$ & Indian & Kumar et al. [18] & No association with TB \\
\hline 93 PTB patients & $103 \mathrm{NC}$ & Iranian & Anoosheh et al. [19] & No association with PTB \\
\hline 151 PTB patients & $83 \mathrm{NC}$ & Iranian & Ghamari et al. [20] & No association with PTB \\
\hline 124 TB patients & $200 \mathrm{NC}$ & Azeri Iranian & Ghorghanlu et al. [21] & No association with TB \\
\hline 128 TB patients & $80 \mathrm{NC}$ & Turkish & Ates et al. [22] & No association with PTB \\
\hline 149 TB patients & $147 \mathrm{NC}$ & Thai & Vejbaesya et al. [23] & No association with TB \\
\hline 185 TB patients & $155 \mathrm{NC}$ & North Indian & Sharma et al. [24] & No association with TB \\
\hline 190 PTB, 183 STB & $362 \mathrm{NC}$ & South Chinese & Zhou et al. [25] & No association with PTB and STB \\
\hline
\end{tabular}




\section{Conclusions}

Our study demonstrated that TNF- $\alpha$ gene -308 G/A polymorphism was associated with susceptibility to PTB and A allele increases the risk of PTB compared to $G$ allele. Our results could give more understanding about TB pathogenesis. Further studies in other ethnic groups, other gene polymorphism and interaction between host gene, host agent, and environment or lifestyle are needed to fully understand and validate this result.

\section{Acknowledgments}

We thank all the subjects for their participation in this study. This work was supported by DRPM Project of Department of Research, Technology, and High Education Republic of Indonesia. (Penelitian Dasar Scheme: No. 5/UN5.2.3.1/PPM/KP-DRPM/2019).

\section{References}

1. World Health Organization. Global Tuberculosis Report 2019. Geneva: World Health Organization Available from: $\quad$ https://www.apps.who.int/iris/bitstream/han dle/10665/329368/9789241565714-eng.pdf?ua=1. [Last accessed on 2018 Oct 01].

2. Raviglione MC, Snider DE Jr., Kochi A. Global epidemiology of tuberculosis. Morbidity and mortality of a worldwide epidemic. JAMA. 1995;273(3):220-6. https://doi.org/10.1001/ jama.1995.03520270054031 PMid:7807661

3. Cheepsattayakorn A, Cheepsattayakorn R. Human genetic influence on susceptibility of tuberculosis: From infection to disease. J Med Assoc Thai. 2009;92(1):136-41. PMid:19260255

4. Schurr E. Is susceptibility to tuberculosis acquired or inherited? J Intern Med. 2007;261(2):106-11. PMid: 17241175

5. Cavalcanti YV, Brelaz MC, Neves JK, Ferraz JC, Pereira VR. Role of TNF-alpha, IFN-gamma, and IL-10 in the development of pulmonary tuberculosis. Pulm Med. 2012;2012:745483. https://doi.org/10.1155/2012/745483 PMid:23251798

6. Engele M, Stössel E, Castiglione K, Schwerdtner N, Wagner M, Bölcskei $\mathrm{P}$, et al. Induction of TNF in human alveolar macrophages as a potential evasion mechanism of virulent Mycobacterium tuberculosis. J Immunol. 2002;168(3):1328-37. https://doi.org/10.4049/jimmunol.168.3.1328

PMid:11801673

7. Keane J, Remold HG, Kornfeld H. Virulent Mycobacterium tuberculosis strains evade apoptosis of infected alveolar macrophages. J Immunol. 2000;164(4):2016-20. https://doi. org/10.4049/jimmunol.164.4.2016
PMid:10657653

8. Mohan VP, Scanga CA, Yu K, Scott HM, Tanaka KE, Tsang E, et al. Effects of tumor necrosis factor alpha on host immune response in chronic persistent tuberculosis: Possible role for limiting pathology. Infect Immun. 2001;69(3):1847-55. https:// doi.org/10.1128/iai.69.3.1847-1855.2001

PMid: 11179363

9. Zhang Z, Fan W, Yang G, Xu Z, Wang J, Cheng Q, et al. Risk of tuberculosis in patients treated with TNF- $\alpha$ antagonists: A systematic review and meta-analysis of randomised controlled trials. BMJ Open. 2017;7(3):e012567. https://doi.org/10.1136/ bmjopen-2016-012567

PMid:28336735

10. Hajeer $\mathrm{AH}$, Hutchinson IV. Influence of TNFalpha gene polymorphisms on TNFalpha production and disease. Hum Immunol. 2001;62(11):1191-9

PMid: 11704281

11. Wilson AG, Symons JA, McDowell TL, McDevitt HO, Duff GW. Effects of a polymorphism in the human tumor necrosis factor alpha promoter on transcriptional activation. Proc Natl Acad Sci U S A. 1997;94(7):3195-9. https://doi.org/10.1073/pnas.94.7.3195 PMid:9096369

12. Gonzalez OY, Adams G, Teeter LD, Bui TT, Musser JM, Graviss EA. Extra-pulmonary manifestations in a large metropolitan area with a low incidence of tuberculosis. Int $J$ Tuberc Lung Dis. 2003;7(12):1178-85. PMid: 14677893

13. Sallakci N, Akcurin G, Köksoy S, Kardelen F, Uguz A, Coskun M, et al. TNF-alpha G-308A polymorphism is associated with rheumatic fever and correlates with increased TNF-alpha production. J Autoimmun. 2005;25(2):150-4. https://doi. org/10.1016/j.jaut.2005.05.005

PMid: 16046099

14. Shahsavar F, Varzi AM, Azargoon A. Association between TNF-308G/A polymorphism and susceptibility to pulmonary tuberculosis in the Lur population of Iran. Asian Pac J Trop Biomed. 2016;6(1):80-3. https://doi.org/10.1016/j. apjtb.2015.09.017

15. Wu S, Wang MG, Wang Y, He JQ. Polymorphisms of cytokine genes and tuberculosis in two independent studies. Sci Rep. 2019;9:2507.

16. Correa PA, Gómez LM, Anaya JM. Polymorphism of TNF-alpha in autoimmunity and tuberculosis. Biomedica. 2004;24 Supp 1:43-51. https://doi.org/10.7705/biomedica.v24isupp1.1301 PMid: 15495570

17. Henao MI, Montes C, París SC, García LF. Cytokine gene polymorphisms in Colombian patients with different clinical presentations of tuberculosis. Tuberculosis (Edinb). 2006;86(1):11-9. https://doi.org/10.1016/j.tube.2005.03.001 PMid: 15925543

18. Kumar V, Khosla R, Gupta V, Sarin BC, Sehajpal PK. Differential association of tumour necrosis factor-alpha single nucleotide polymorphism (-308) with tuberculosis and bronchial asthma. Natl Med J India. 2008;21(3):120-2.

PMid:19004142

19. Anoosheh S, Farnia $P$, Kargar M. Association between TNF-Alpha (-857) gene polymorphism and susceptibility to tuberculosis. Iran Red Crescent Med J. 2011;13(4):243-8.

PMid:22737473

20. Ghamari E, Farnia P, Saif S, Marashian M, Ghanavi J, Farnia P, et al. Comparison of single nucleotide polymorphisms [SNP] at TNF- $\alpha$ promoter region with TNF receptor 2 (TNFR2) in susceptibility to pulmonary tuberculosis; using PCR-RFLP technique. Am J Clin Exp Immunol. 2016;5(4):55-61. https://doi. org/10.1016/j.jjmyco.2016.09.038 


\section{PMid:28078191}

21. Ghorghanlu S, Asgharzadeh M, Samadi-Kafil H, Khaki-Khatibi F Rashedi J, Mahdavi Poor B, etal. TNF- $\alpha-308$ G/A polymorphism and susceptibility to tuberculosis in Azeri population of Iran. Genetika. 2016;48(3):819-26. https://doi.org/10.2298/gensr1603819g

22. Ates $O$, Musellim B, Ongen G, Topal-Sarikaya A. Interleukin-10 and tumor necrosis factor-alpha gene polymorphisms in tuberculosis. J Clin Immunol. 2008;28(3):232-6. https://doi. org/10.1007/s10875-007-9155-2

PMid:18071881

23. Vejbaesya S, Chierakul N, Luangtrakool P, Sermduangprateep C. NRAMP1andTNF- $\alpha$ polymorphismsandsusceptibilitytotuberculosis in Thais. Respirology. 2007;12(2):202-6. https://doi.org/10.1111/ j.1440-1843.2006.01037.x

PMid:17298451

24. Sharma S, Rathored J, Ghosh B, Sharma SK. Genetic polymorphisms in TNF genes and tuberculosis in North Indians. BMC Infect Dis. 2010;10:165. https://doi. org/10.1186/1471-2334-10-165

PMid:20537163

25. Zhou Y, Tan CY, Mo ZJ, Gao QL, He D, Li J, et al. Polymorphisms in the SP110 and TNF- $\alpha$ gene and susceptibility to pulmonary and spinal tuberculosis among Southern Chinese population. Dis Markers. 2017;2017:4590235. https://doi. org/10.1155/2017/4590235

PMid:29430075

26. Banerjee N, Nandy S, Kearns JK, Bandyopadhyay AK, Das $\mathrm{JK}$, Majumder $\mathrm{P}$, et al. Polymorphisms in the TNF- $\alpha$ and IL10 gene promoters and risk of arsenic-induced skin lesions and other nondermatological health effects. Toxicol Sci. 2011;121(1):132-9. https://doi.org/10.1093/toxsci/kfr046 PMid:21357384

27. Ben-Selma W, Harizi H, Boukadida J. Association of TNF- $\alpha$ and IL-10 polymorphisms with tuberculosis in Tunisian populations. Microbes Infect. 2011;13(10):837-43. https://doi.org/10.1016/j. micinf.2011.04.009

PMid:21609779

28. Cui G, Wang H, Li R, Zhang L, Li Z, Wang Y, et al. Polymorphism of tumor necrosis factor alpha (TNF-alpha) gene promoter, circulating TNF-alpha level, and cardiovascular risk factor for ischemic stroke. J Neuroinflammation. 2012;9:235. https://doi. org/10.1186/1742-2094-9-235

PMid:23050663

29. Yi YX, Han JB, Zhao L, Fang Y, Zhang YF, Zhou GY. Tumor necrosis factor alpha gene polymorphism contributes to pulmonary tuberculosis susceptibility: Evidence from a metaanalysis. Int J Clin Exp Med. 2015;8(11):20690-700.

PMid:26884992

30. Sinaga BYM, Siregar $Y$, Amin M, Sarumpaet S. Effect of smoking and alcohol consumption on pulmonary tuberculosis among Batak ethnic population in Medan, Indonesia. IOP Conf Ser Earth Environ Sci. 2018;125:012139. https://doi. org/10.1088/1755-1315/125/1/012139

31. Correa-Macedo W, Cambri G, Schurr E. The interplay of human and Mycobacterium Tuberculosis genomic variability. Front Genet. 2019;10:865. https://doi.org/10.3389/fgene.2019.00865 PMid:31620169 